\title{
Translational Reading: Definition, Types, Specifics
}

\author{
Victoria Kurilenko ${ }^{1}$, Yulia Biryukova ${ }^{1 *}$, Kristina Akhnina ${ }^{1}$, Tatiana Cherkashina ${ }^{2}$, and Nina Romanova ${ }^{3}$ \\ ${ }^{1}$ Peoples' Friendship University (RUDN University), Moscow, Russia \\ ${ }^{2}$ Kosygin Russian State University, Moscow, Russia \\ ${ }^{3}$ Bauman Moscow State Technical University
}

\begin{abstract}
The article analyzes various types of reading relevant to translators of specialized texts to provide a flexible transition from one type of reading to another, depending on a task in hand. The analysis of researches and interviews with professional translators has shown that translators use in their work different types of reading such as: survey, study and search reading, skimming, analytical, synthetic and philological reading, and editing. The use of certain types of reading is conditioned by the tasks facing translators at various stages of their work (including the professionally oriented, analytical, synthetic, and corrective stages). The survey involved 42 translators from Russia, Belarus, France, the Czech Republic, Latvia, Germany, Finland, and the Netherlands. The interviewed translators were representatives of various translation agencies and joint ventures as well as freelance translators.
\end{abstract}

\section{Introduction}

In their work, translators of specialized texts repeatedly turn to translational reading, which is a more complex type of speech activity and has its own specific features that distinguish it from unprofessional reading.

We call this type of reading "translational", which is understood as a receptive component of translations of scientific and technical texts, i.e., perception, understanding and interpretation of the content and language form of foreign-language texts. As a result, translators develop the objective sense of a source text, based on which a target text is created.

A mastery of translation reading, which, depending on the stage of translation, has various shades, is the key to a professional translator's success. In this case, the question arises: What types of reading will be used by professional translators of specialized texts?

\section{Types of reading}

Translators of scientific and technical texts are faced with certain professional tasks to be fulfilled using various types of reading. Researchers consider the types of reading as a set of operations determined by the purpose of reading and characterized by "a specific combination of methods for the semantic and perceptual processing of visually perceived material" [1: 30]. The question of types of reading is discussed in considerable detail in the methods of teaching languages. Currently, researchers identify more than 30 types of reading. Most known types of reading are differentiated in pairs, and various factors/criteria are used to distinguish them. Researchers distinguish the types of reading according to: (1) the form of reading: oral/silent reading [2], [3]; (2) the use of logical operations: synthetic/analytical reading [2]; (3) the depth of penetration into the content: intensive/extensive reading [4]; and (4) the objectives of communicative tasks: study reading, survey reading, skim reading, and search reading [1].

The types of reading, considered by researchers depending on the communicative tasks being solved, served as the basis for differentiating professionally oriented types of reading. They are defined based on the types of reading identified by Z.I. Klychnikova (analytical and synthetic reading) and S.K. Folomkina (survey, study, skim, and search reading).

Translational reading is professionally oriented, and translators also use different types of reading in their work, depending on the tasks facing them. Let us consider in detail the types of reading identified by researchers.

Synthetic and analytical are related to the concepts of analysis and synthesis and are linked together as a single process. Analytical reading is characterized by understanding a text through its specific linguistic forms, where there is a comparison between new and previously obtained information and between the author's various statements. This type of reading implies developing one's own assessment and attitude to what has been read through the lens of the reader's experience. In synthetic reading, information in a text is perceived holistically, and the reader does not need a dictionary. Note that unfamiliar material should not be an obstacle for this type of reading. These types of reading, when learning a foreign language, according to Z.I. Klychnikova, should be used in a complex

\footnotetext{
* Corresponding author: yu.birukova@ gmail.com
} 
at the initial and advanced training stages [2: 80-86]. For translators, these types of reading are likely to be important in carrying out a translation analysis, which is an important component of their work during the understanding stage. However, translators, being only mediators in intercultural communication, should not develop their own attitude to the material presented and they should refrain from evaluating what they have read.

Study reading is a type of reading, the result of which is a complete $(100 \%)$ and accurate understanding of all facts available in the text. According to S.K. Folomkina, study reading implies extracting what is "very important for the reader, who tries not only to understand as accurately as possible but also to critically comprehend information". The reader is supposed to be using the obtained information hereafter. Therefore, the reader is committed to long-term memorization. For this reason, study reading can often be slow, accompanied by stops or returns to specific text sections [1: 33]. This type of reading can also be used by translators of scientific and technical texts, but critical text comprehension does not appear relevant for their work, since the information contained in a given text is intended not for its translator but for the recipient of its translation [5].

S.K. Folomkina considers survey reading as a type of reading, where the reader identifies the most significant information. The degree of understanding for this type of reading is $70-75 \%$. At the same time, as the researcher notes, "the understanding of basic information should be accurate, and the understanding of secondary information should be correct and not distorted". In this case, the reader does not need to completely understand the text. An incomplete understanding can be used for various reasons, e.g., to refresh memory about some information that is forgotten but may be required for any purpose or to restore information omitted for a certain reason if, after preliminary reading, the meanings of some words have remained obscure [1: 33-34]. This type of reading is also essential for translators of scientific and technical texts, because, to fully and accurately understand the meaning of the source text, they have to repeatedly return to sections, words, expressions, etc. that are difficult to understand.

Skimming allows the reader to get a general idea of an article, a book, a text, or a journal without entering into details of the presented information. This type of reading is used during the first insight into publications to determine whether "they contain any necessary/interesting information, based on which a decision is made whether it is "needed/not needed"; or to refresh memory of what was previously read; or when selecting materials for a specific purpose and further work; or when selecting written materials on a specific issue for the purpose of further abstracting, reviewing, etc." [1: 35]. Skimming is also important for translators of scientific and technical texts at the stage of reading and understanding a foreign-language text. Translators will use it to determine their own knowledge of the forthcoming translation subject and the need for a reference information search.

Search reading implies finding specific information necessary for the readers. They find in the text single words, phrases or sentences that help them conclude whether it contains the required information. The subject of information being viewed is assessed only in terms of its importance to the readers. If this information is unimportant, they stop reading. If it is required, they change the type of reading. In the case of search and skim reading, it is difficult to determine the completeness of understanding in percentage form. The main thing is whether the result is achieved [1: 35-36]. This type of reading is important for translators of scientific and technical texts when they search for reference information necessary for understanding and interpreting a foreignlanguage text.

All of the aforesaid allows us to assume that, when translating scientific and technical texts, translators will use various types of reading. Researchers note that, depending on the nature of professional activity, professionally oriented reading, along with its general specificity, acquires new specific features.

\section{Types of professional reading}

Teachers use pedagogical reading in their professional work when preparing for classes, checking students' written statements, organizing and conducting discussions, analyzing literary works, or improving their qualifications [6], [7]. As applied to the sociopolitical sphere, discourse reading is distinguished and analyzed, which is distinguished by the completeness, accuracy and depth of understanding and allows specialists to immerse themselves in the historical and sociocultural context of the text origin, dissemination and functioning [8: 80]. Identified by researchers abstractive reading is relevant in a referent's professional work; the result of this reading is an abstract composed of the main provisions/theses of the text [9: 2834]. Also, integration reading is selected, where specialists receive information during the reading process and, after reading, involve additional sources related to the subject matter, thus achieving their own understanding on this issue [10: 45]. Philological reading can be used in a philologist's work. It is based on a deep perception and understanding of the context as well as on the knowledge of various means that the authors use in their work [11], [12], [13], [14]. Editing is applicable to an editor's work: it is associated with the editorial analysis of received texts and texts appearing in the editing process [15].

An analysis of professionally oriented types of reading has shown that specialists, depending on the tasks they are faced with, flexibly use different types of reading, smoothly passing from one type to another, within the framework of their professional reading.

It should be noted that researchers have repeatedly attempted to use these types of reading for training translators. Thus, O.V. Perlova proposed using philological reading for this purpose [13: 92, 94], [16]. At the assessment level of philological text interpretation, the author point out the ability to make notes and personal comments fixing the reader's attitude to the selected information. It seems inexpedient to develop this skill when training future translators of scientific and technical texts, since they do not need to express their personal attitude to information received or critically evaluate it. On the contrary, they will prevent 
translators creating the target text. As noted above, translators should refrain from their own evaluations and emotions.

\section{Methodology}

In order to consider the types of reading when solving problems facing translators, N.N. Gavrilenko proposed an integrative translation teaching model [5]. This model makes it possible, based on the activity approach, to gradually form types of translational reading in the process of solving the tasks facing translators. This model is based on the sequence of actions of a translator as a member of a professional group that carries out their activities in a certain communicative situation. This approach allowed the author to identify the main training stages corresponding to the translator's work stages, namely:

- The professionally oriented stage: receiving the source text from the employer, getting prepared for professional activity;

- The analytical stage: understanding and interpreting a foreign-language text (perceiving, retrieving reference information, translating, developing a translation strategy)

- The synthetic stage: searching for equivalents and terms, creating the target text;

- The correcting stage: correcting and editing the target text; delivering the completed translation to the customer.

In order to find out what type of reading will be used at each stage of translation, a survey of translators of scientific and technical texts was conducted. The survey was conducted during 2016-2017, involving 42 translators from Russia, Belarus, France, the Czech Republic, Latvia, Germany, Finland, and the Netherlands. The interviewed translators included representatives of various translation agencies and joint ventures as well as freelance translators.

The translators were offered a list of different types of reading with definitions and a sequence of translation tasks [17], [18]. Having read the definitions, the translators were to refer each translation tasks to types of reading that, in their view, should be used to solve it. They were also asked to indicate in the questionnaire what information resources they use when reading scientific and technical texts at each of these stages.

\section{Results}

The analysis of types of professionally oriented types reading interviews with the translators made it possible to correlate the stages with the tasks of various types of reading used by translators in their work. These types of reading are listed in Table 1.
Table 1. Types of reading used by translators of special texts.

\begin{tabular}{|c|c|c|}
\hline $\begin{array}{l}\text { TRAINING } \\
\text { STAGE }\end{array}$ & $\begin{array}{c}\text { TRAINING } \\
\text { STAGE TASKS }\end{array}$ & $\begin{array}{c}\text { TYPES OF } \\
\text { TRANS- } \\
\text { LATIONAL } \\
\text { READING }\end{array}$ \\
\hline \multirow[t]{2}{*}{$\begin{array}{l}\text { The } \\
\text { professionally } \\
\text { oriented } \\
\text { stage: }\end{array}$} & $\begin{array}{l}\text { Determining the } \\
\text { degree of self- } \\
\text { awareness in the } \\
\text { matter }\end{array}$ & Skimming \\
\hline & $\begin{array}{c}\text { Selecting reference } \\
\text { materials }\end{array}$ & $\begin{array}{l}\text { Search reading } \\
\text { Survey reading } \\
\end{array}$ \\
\hline \multirow[t]{2}{*}{$\begin{array}{l}\text { The analytical } \\
\text { stage }\end{array}$} & $\begin{array}{l}\text { Understanding } \\
\text { 1. Reference } \\
\text { information } \\
\text { retrieval } \\
\begin{array}{c}\text { 2. Translational } \\
\text { analysis }\end{array}\end{array}$ & $\begin{array}{l}\text { Skimming; } \\
\text { Search reading } \\
\text { Critical reading; } \\
\text { philological } \\
\text { reading }\end{array}$ \\
\hline & Translation strategy & Skimming \\
\hline \multirow{4}{*}{$\begin{array}{l}\text { The synthetic } \\
\text { stage }\end{array}$} & Searching for terms & Search reading \\
\hline & Target text creating & $\begin{array}{l}\text { Skimming; } \\
\text { Study reading } \\
\text { (not always) }\end{array}$ \\
\hline & $\begin{array}{l}\text { Selected strategy } \\
\text { correcting }\end{array}$ & Synthetic reading \\
\hline & $\begin{array}{l}\text { Introducing new } \\
\text { translated fragments } \\
\text { into Translation } \\
\text { Memory termbases }\end{array}$ & Search reading \\
\hline \multirow{2}{*}{$\begin{array}{l}\text { The } \\
\text { correcting } \\
\text { stage }\end{array}$} & $\begin{array}{c}\text { Unifying terms, } \\
\text { clarifying the } \\
\text { sequence of applied } \\
\text { definitions and terms }\end{array}$ & Editing \\
\hline & $\begin{array}{l}\text { Checking the } \\
\text { selected text } \\
\text { translation strategy, } \\
\text { assessing the quality } \\
\text { of the completed } \\
\text { translation }\end{array}$ & Analytical reading \\
\hline
\end{tabular}

The analysis of researches has shown that translators use in their work different types of reading such as: survey, study and search reading, skimming, analytical, synthetic and philological reading and editing.

The use of a certain type of reading is conditioned by the tasks facing translators at various stages of their work.

References 
1. S.K. Folomkina, Teaching reading in a foreign language in a non-linguistic institution (Moscow: Vysshaya Shkola Publ., 2005)

2. Z.K. Klychnikova, Psychology of reading (Moscow: Prosveshchenie Publ., 1975)

3. Maley, A. Duff The Inward Ear: Poetry in the Language Classroom (Cambridge: CUP, 1993)

4. S.F. Shatilov, Actual methodological problems of teaching Russian to foreign students (Leningrad: LSU Publ., 1985)

5. N.N. Gavrilenko, Linguistic and methodical basics of training translators from foreign languages into Russian in the field of science and technology (by the example of translation from French into Russian): Doc. Sci. (Philology) thesis. (Moscow, 2006).

6. T.G. Agapitova, Teaching foreign-language informative reading in the conditions of forming the professional culture of future foreign-language teachers: Cand. Sci. (Pedagogics) thesis, (Perm, 2002)

7. N.A. Ippolitova, Reading in the teacher's professional activity, (Pedagogical rhetoric: Workbook. Moscow, 2001)

8. S.V. Ivanov, Methods of teaching discourse reading in a foreign language to students of sociopolitical specialties: Cand. Sci. (Pedagogics) thesis, (St. Petersburg, 2011)

9. I.K. Gapochka, The goals and content of abstractive reading in the Russian (foreign) language, Teaching Russian to foreign graduate students. (Moscow, 1981)

10. W.Grabe, F.Stoller Teaching and Researching Reading (Longman: Pearson Education, 2004)

11. N.F.Koryakovtseva, Text as a material for teaching philological reading techniques. Text in the learning process: Col. Papers 282 (Moscow: MSLU Publ., 1987)

12. Ye. L. Maryanovskaya, The interconnected formation of communicative and educational competencies in teaching home reading to students in a language university: Cand. Sci. (Pedagogics) thesis, (Ryazan, 2007)

13. O.V. Perlova, Methodology of teaching philological reading as a component of professional training (the English language, language university): Cand. Sci. (Pedagogics) thesis, (Moscow, 2009)

14. A.V. Rubtsova, Proc. of the Inter. Sci. Conf. (St. Petersburg (St. Petersburg: Remone Publ., 2012)

15. L.A. Konstantinova, Stylistics and literary editing. (Tula, 2007)

16. E. Malushko, O. Maletina, V. Tsybaneva, ASSEHR 97, 175-180 (2017)

17. E. Yu. Malushko, International Multidisciplinary Scientific Conferences on Social Sciences and Arts, 1155-1160 (2015)

18. E. Malushko, O. Maletina, V. Lizunkov, V. Tsybaneva, International Multidisciplinary Scientific
Conferences on Social Sciences and Arts, 481-487 (2016) 